\title{
Сопоставительный анализ взглядов Н. И. Костомарова и П. А. Кулиша об исторической роли и эпохе Богдана Хмельницкого
}

\author{
БЕАТА ВАРГА \\ VARGA Beáta, SZTE BTK Újkori Egyetemes Történeti Tanszék, H-6722 Szeged, Egyetem u. 2. \\ Department of Modern World History, Faculty of Arts, University of Szeged \\ E-mail: varga.bea@hist.u-szeged.hu
}

(Received: 2 December 2017; accepted: 15 February 2018)

\begin{abstract}
N. Kostomarov's views in the second half of the 19th century reflected the ambitions of the Ukrainian bourgeois-noble national circles that fought for the national autonomy of Ukraine within the framework of the Russian Empire. P. Kulish had slightly different views from those of Kostomarov: he called Khmelnytsky a selfish politician whose actions were only guided by his egotistic purposes. We can interpret Kulish's work as a strong criticism of and attack on the democratic Ukrainian national movement that from the middle of the 19th century "discovered" and idealized Khmelnytsky and his movement.
\end{abstract}

Keywords: N. Kostomarov, P. Kulish, B. Khmelnytsky, Ukrainian national movement, Russian Empire

В современной украинской историографии утвердилось то мнение, что Пантелеймон Александрович Кулиш и Николай Иванович Костомаров стали символами украинского национального возрождения (Пинчук 2012: 480, ЛАЗАРЕВА 2015: 12). Они познакомились осенью 1844 г. и до смерти Костомарова дружили (КРАВчЕнко 2006: 254), сотрудничали, поддерживали творческие отношения и научную дискуссию в своих статьях и письмах (СвітЛЕнКО 2016: 30).

Н. И. Костомаров и П. А. Кулиш написали сотни книг и статей, поэтому автор этой статьи выбрал только несколько таких характерных работ, с помощью анализа которых можно сопоставить исторические взгляды на данную тему в разные периоды творчества деятелей украинского просвещения.

Н. И. Костомаров родился внебрачным ребенком русского казака-переселенца и его крепостной крестьянки. Из-за ранней смерти своего отца он остался крепостным до 1832 г. Его мать выкупила сына из крепостничества и Костомаров смог поступить в Харьковский университет. Выводы его диссертации под названием «О причинах и характере унии в Западной России» в 1841 г. расходились с официальной историографией, поэтому ему не разрешили защититься. В этом первом «произведении» Н. И. Костомаров характеризовал украинского гетмана следующим образом: «Не Хмельницкий был действующим лицом, а народ, не Хмельницкий воззвал народ к восстанию, 
а народная потребность вывела его из бездействия... Присоединение Малороссии к Московии можно назвать делом Хмельницкого... но освобождение от Польши - никогда...» (КостомАРОв 1928b: 32). Костомаров в своей диссертации решительно осудил деятельность гетмана за его эгоистичность и честолюбие, и в то же время как представитель народнического направления, ученый прославлял народные массы, которые он считал решающей силой истории. По его мнению, гетман первоначально поднял знамя за православную веру, но вместе с этим призывом вспыхнула и «великая борьба за свободу совести, за независимость страны...» (КостомАРов 1928b: 31). Самой большой ошибкой гетмана стало то, что свой план он не довел до конца (КостомАРОВ 1928b: 32). В историографии рассматривают исследующую данную тему диссертацию Костомарова как на появление элементов украинской национальной идеи (Пинчук 2012: 397).

П. А. Кулиш родился в семье землевладельца, не имевшего на дворянство документов, и дочери казацкого сотника, но их сына власти - в дальнейшем - признавали дворянином. Он посещал лекции в Киевском университете, потом в 1843 г. начал работать в качестве сотрудника Киевской археографической комиссии (КРАВченко 2006: 255) под руководством М. Максимовича. В 1845 г. был приглашен в Петербургский университет на должность преподавателя русского языка для иностранных студентов. Увлеченный казацкой стариной Кулиш в 1843 г. написал «Книгу о делах народа украинского и славного войска казацкого запорожского», в которой упрекал украинцев за их скупую историческую память: «уже только немногие из нас знают, что значит Гетманщина, что значит Украина, что значит казачество... На что ж нам пригодится знать, кто такой был... Александр Македонский... когда мы не знаем, чем славен был... Богдан Хмельницкий... и множество других рыцарей, славных и умом и оружием превыше греческих и римских полководцев?» (Кулиш 1843: 66).

На рубеже 1845-1846 годов молодые киевские интеллектуалы, преданные идее народности, славяно- и украинофильству, создали тайное КириллоМефодиевское братство. Вместе со своими друзьями П. А. Кулиш и Н. И. Костомаров осуждали крепостнический и деспотический строй самодержавной России, исповедовали идеалы будущей федерации, построенной на демократических принципах. Именно Костомаров стал автором ${ }^{1}$ основного программного документа «братчиков», т. н. «Закона Божия», в котором идеалом мирового общественно-политического развития представлено украинское казачество (КостомАРОв 1990: 19-20).

В марте 1847 года основатели общества были арестованы. Костомарова приговорили к годичному заключению в Алексеевском равелине Петропавловской крепости, а после этого он служил в Саратове под надзором и не по

\footnotetext{
${ }^{1}$ На самом деле в решении судебного дела 1847 года Костомарова считали не автором програмного документа, а обвиняли в том, что он «дал ход» преступной рукописи «Закон Божий».
} 
профессии. Вынесенный Кулишу приговор за «неумеренное в неправильных понятиях о Малороссии...» (Товариство 1990: 69) состоял только в четырехмесячном заключении в Петропавловскую крепость и ссылке в Вятку, потому что он «показывал искреннее сожаление о прежнем своем заблуждении» (Товариство 1990: 69). Но поскольку никаких конкретных преступлений ему инкриминировано не было, уже в 1850 г. он получил разрешение вернуться в Санкт-Петербург.

После смерти Николая I и в связи с коронацией Александра II в августе 1856 г. Костомаров был амнистирован, ему разрешили печататься, но он остался служить в Саратове (1847-1859) и готовил к печати свои работы там. В 1859 г. с позволения императора ученый был утвержден в звании экстраординарного профессора при Санкт-Петербургском университете.

В 1857-1858 гг. было опубликовано написанное Н. И. Костомаровым трехтомное историческое исследование «Богдан Хмельницкий». Во время саратовской ссылки необходимыми источниками историка снабжал поляк граф Свидзинский, помощь которого Костомарову П. А. Кулиш объясняет «польским антагонизмом к русскому правительству и надеждой, что автор „Богдана Хмельницкого“ перенесет наследственную неприязнь к Польше на Москву...» (Кулиш 1885: 68-69).

Костомаров уже в конце 1845 г. начал работать над монографией и прочитал ее введение М. А. Максимовичу, который в своем письме М. П. Погодину критиковал Костомарова с точки зрения некорректного использования источников и имен исторических фигур, но написал и следующее: «...прекрасный труд г. Костомарова... написан не в виде систематической истории, а рассказа... Такая форма сочинения дала возможность автору... провести в массу читателей богатство сведений о столь любопытной в важной эпохе русской жизни, каково девятилетнее гетманство Богданово...» (МАКсимович 2004: 192-195).

В то же время, после выхода в свет первого издания «Богдана Хмельницкого» Костомарова, в 1856-1857 гг. были опубликованы двухтомные «Записки о Южной Руси» П. А. Кулиша. Это произведение являло собой переход историка от романтического восприятия истории украинского народа к историко-этнографическому реализму. Кулиш уже пишет в критическом тоне о казаках (Кулиш 1856: 82, 245), но в то же время оценивает историческую роль Богдана Хмельницкого вместе с казаками в целом положительно: «...эти выходцы унесли с собою в степи воспоминания о всеобщей войне „благочестивых“ с католиками, и угнетенных с угнетателями под предводительством Хмельницкого...» (Кулиш 1856: 91).

К началу 60-х гг. ХІХ в. Костомаров характеризовал гетмана следующим образом: «Богдан Хмельницкий, человек глубоко народный... стоял выше своего века... Соединяя с великорусским народом Казацкую Украину... не хотел ограничиться с этим, и оставлять начатое дело прежде восстановления независимости и цельности всего южно-русского края...» (КостомАРОВ 1928a: 153-154). 
Как государственный служащий, Кулиш в 1864 г. переезжает по новому назначению в Варшаву, где знакомится с польскими источниками казацких времен. В 1871 г. он возвращается в Российскую империю, и продолжая исследовать историю украинского казачества, приходит к выводу о неспособности казачества создать собственное государство. С этих позиций была написана работа «Казаки по отношению к государству и обществу». В данном произведении автор решительно выступает против идеализации казачества и представляет казаков как деструктивную силу, лишенную идеалов государственности. «Ни Хмельнищина, ни Колиивщина не оставили по себе никаких общественных учреждений, ни даже попыток устроить что-нибудь ко благу общества в религиозном, просветительном и экономическом отношении...» (Кулиш 1877a: 366). Самой позорной стороной эпохи Хмельницкого Кулиш считает его сообщество с врагами христианства (Кулиш 1877b: 130).

На вышеприведенную статью П. А. Кулиша Н. И. Костомаров ответил в своей статье «О козаках» таким образом, что по его мнению Кулиш, считавшийся ранее фанатиком Малороссии и поклонником казатчины, совершенно изменил свои воззрения на все малорусское и стал фанатиком беспристрастия. Статью П. А. Кулиша можно назвать катехизисом учения преобразившегося историка, ведь он стремился убедить своих читателей, что казаки были не более как разбойники, вредные для государства и враги монархической власти (Кулиш 1877a: 352-355). Опровергая ошибочность подобных взглядов, Костомаров ставил вопрос: «Будто так? Спросим г. Кулиша: как Хмельнищина не оставила по себе никакого общественного учреждения? А гетманщина, существовавшая после Хмельницкого с лишком двести лет, разве это не общественное учреждение...?» (КостомАРОв 1903: 626).

\section{Сопоставительный анализ фундаментальных работ Н. И. Костомарова «Богдан Хмельницкий» и П. А. Кулиша «Отпадение Малороссии от Польши»}

Н. И. Костомаров в своей монографии «Богдан Хмельницкий» выделяет, что после Земского собора 1 октября 1653 года, на котором было решено объявить войну Польше и Литве за оскорбление веры и царской чести, царь отправил послов в Переяслав для принятия Украины под покровительство московского царя (КостомАРОв 1870: 127). А в связи с решением Земского собора П. А. Кулиш в своей книге «Отпадение Малороссии от Польши» пишет о том, что в критический момент, когда казаки потерпели фатальное поражение (Кулиш 1889: 402), к ним готовились ехать полномочные послы от царя для принятия Малороссии в Московское подданство, а не под покровительство, как написал Костомаров. По убеждению Кулиша, казаки враждебно относились к Москве и в этом коренилась причина казацких предательств от Хмельницкого до Мазепы и Орлика - этим объяснялся предательский характер казачества (Кулиш 1889: 402). 
Н. И. Костомаров считает решающим моментом Переяславскую Раду 8 января 1654 г., где Богдан Хмельницкий прочитал подготовленные условия, на которых Украина должна соединяться с Москвой (КостомАРов 1870: 131). А московская делегация после присяги казаков от имени монарха дала обещание, что государь будет держать всю Малую Россию под своим покровительством и при ненарушимом сохранении всех их древних прав (КостоМАРОВ 1870: 134-135). Почти совсем по-другому пишет о Переяславской Раде П. А. Кулиш, где «Козацкий Батько» произнес речь и только волей и неволей признал, что «нельзя, видно, жить нам более без царя...» (Кулиш 1889: 403). Кулиш безапелляционно замечает, что «ни условий, ни так называемого Переяславского договора с царскими уполномоченными не было и, по духу московского самодержавия, быть не могло...» (Кулиш 1889: 404). Историк с убеждением пишет, что послы говорили с казаками повелительно и «милость, милость и милость, больше ничего козаки не слышали от царских уполномоченных...» (Кулиш 1889: 404).

Сравнивая взгляды историков в их фундаментальных трудах об исторической роли Богдана Хмельницкого, можно сделать вывод, что в отличие от Кулиша Костомаров отводил казачеству важную роль и видел в Богдане Хмельницком талантливого политика и дипломата, выдающегося полководца. Особенность исторической роли Богдана Хмельницкого он видел в том, что Хмельницкий, считая самой важной своей целью создание независимого украинского государства, был способен признать невозможность долговременного существования суверенной Украины между соседними великими державами. В то же время Костомаров высказал и свое убеждение, что благодаря присоединению Украины к России царская самодержавная система препятствовала украинской национальной эволюции. Костомаров считал важным подчеркнуть и тот момент, что добровольное присоединение гетман выбрал по необходимости и в отсутствии других альтернатив. Акт соединения двух народов ученый называет не воссоединением, хотя в данный исторический момент признает это событие необходимым. А в 70-80-е гг. XIX в. историк расширил взгляды на историческую роль гетмана до признания за ним цели «дать своей Украине полную независимость, хотя не мог сам отрешиться от усвоенного с юности идеала шляхетского строя...» (КостомАРОВ 1882: 2, Пинчук 1984: 132).

А П. А. Кулиш характеризовал гетмана свирепым разбойником: «Никто не был столь разительным олицетворением вопиющих камней, как этот жестокосердый Хмель с бессмысленными и беспощадными орудиями его мстительности - казаками...» (Кулиш 1888: 329). Самой большой ошибкой гетмана Кулиш считал, что он не признал важность воссоединения Малороссии с Россией, и смотрел на это событие как на неизбежное, но временное зло. Работу Кулиша можно считать серьезной критикой украинского национального движения во второй половине XIX в., «исследующей» важность эпохи Богдана Хмельницкого. 


\section{Заключение}

Исторические концепции Н. И. Костомарова в научных кругах всегда вызывали непрекращающиеся споры (см. Пинчук 2012: 143). В современной украинской историографии специалисты в области «костомарововедения» (Пинчук 2012: 412, ГончАР 2017: 5) высоко оценивают творческое наследие историка в первую очередь за его роль в национальном движении за независимость Украины.

Творчество «русского и украинского Костомарова» (БСЭ 1973: 275) характеризуется повышенным интересом к народам и истории народных движений. Н. И. Костомаров выделял важность исторической роли народных масс, хотя был очень высокого мнения о Хмельницком (КозАчок 2004: 108, Пинчук 2012: 104, 143). На протяжении всей своей творческой жизни Костомаров никогда не сходил с пути народнического направления (Пинчук 2012: 143). Мы согласны с английским историком Д. Сондерсом, который заключает, что Костомаров хотя и не изменил своим убеждениям молодости, но стал осторожнее в их проявлении, а постоянный поиск компромисса заставлял его с помощью эзопового языка маскировать собственные мысли (см. СондЕРС 2001).

В отличие от Кулиша общественно-политические взгляды Костомарова оставались постоянными в своей основе. Тем не менее, следует отметить, что в отношении монархической власти взгляды Костомарова постепенно менялись: как член Кирилло-Мефодиевского общества он еще считал необходимым упразднение самодержавия, но под влиянием реформ 1860-х гг., в условиях усиления революционно-демократических настроений в обществе, Костомаров стал более терпимым к самодержавию.

В отличие от Костомарова, П. А. Кулиш постепенно подвергал критике взгляды молодости и в пожилом возрасте он во многом не разделял надежд и идеалов, присущих ему в молодости (Ясь 2008: 239). Исчерпав свой прежний юношеский романтизм (Світленко 2016: 31), историк в зрелом возрасте склонялся к положительной оценке факта воссоединения Украины с Россией. «Воссоединение» двух народов (Ясь 2007: 97) считал справедливым и неизбежным историческим актом по причине того, что украинцы в середине XVII века были неспособны создать государство в силу отсутствия элиты, которая не руководствовалась бы эгоистическими интересами (см. ЛАЗАРЕВА 2015: 175).

К 70-м годам XIX в. Кулиш окончательно отвергал свое прежнее, романтическое восприятие исторического прошлого Украины, в том числе и эпохи Богдана Хмельницкого. Негативные отзывы о казаках и Богдане Хмельницком как деструктивных явлениях в украинской истории особенно усилились в его трехтомной монографии «Отпадение Малороссии от Польши (1340-1654)». Мнение П. А. Кулиша на самом деле означало принятие господствовавших в официальной имперской историографии взглядов на прошлое присоединенных земель и народов. 
Сопоставляя характеристику историков об эпохе Богдана Хмельницкого можно сделать следующий вывод. В то время как для Костомарова история украинского казачества была одной из самых важных тем, и восторженное отношение к казачеству сохранилось у него до конца жизни (ГончАР 2017: $205)$, отношение Кулиша к казакам и Богдану Хмельницкому с течением времени радикально изменилось в негативном направлении.

\section{Литература}

БСЭ 1973 = Большая советская энииклопедия. Т. 13. Москва, 1973.

ГОНЧАР 2017 = ГОНЧАР О. Т. Микола Костомаров. Постать історика на тлі епохи. Київ, 2017.

КОзАчоК 2004 = КОзАчоК Я. Украӥнська ідея: з вузької стежки на широку дорогу (художня та науково-публічистична творчість Миколи Костомарова). Київ, 2004.

КОСТОМАРОВ $1870=$ КостОМАРОВ Н. И. Исторические монографии и исследования. Т. 11. Богдан Хмельниикий. Т. 3. Санкт-Петербург, 1870.

КостОМАРОВ $1882=$ КостомАРОВ Н. И. Рецензия на кн.: Буцинский П. Н. О Богдане Хмельницком. Южный край 1882. № 693.

КОСТОМАРОВ 1903 = КОСТОМАРОВ Н. И. О козаках - по поводу статьи П. А. Кулиша, напечатанной в 3-й и 6-й тетрадях «Русского Архива», изд. 1877 года. В кн.: КостомАРОв Н. И. Исторические монографии и исследования. Т. 14. О козаках. Санкт-Петербург, 1903. 615-631.

КостомАРОВ 1928a = КостомАРОВ Н. И. Князь Владимир Мономах и казак Богдан Хмельницкий. В кн.: Науково-публічистичні і полемічні писання Костомарова. Київ, 1928. 149-155.

КОСТОМАРОВ $1928 \mathrm{~b}=$ КостОМАРОВ Н. И. О причинах и характере унии в Западной России. В кн.: Науково-публіџистичні і полемічні писання Костомарова. Київ, 1928. $1-40$.

КОСТОМАРОВ 1990 = КОСТОМАРОВ М. І. Книга буття украӥнского народу. Київ, 1990. КРАВЧЕНКО 2006 = КРАВЧЕНКО О. П. КУЛИш та М. Костомаров: до исторії взаемин. Психолого-педагогічні проблеми сільської школи. Вип. 17. Київ, 2006. 253-260.

Кулиш $1843=$ Кулиш П. А. Книга о ділах народу українського і славного Війська козацького Запорозького (№ 46, 1843). В кн.: Кирилло-Мефодіївське товариство. Т. 2. Київ, 1990. 66-80.

Кулиш 1856 = Кулиш П. А. Записки о Южной Руси. Т. 1. Санкт-Петербург, 1856.

Кулиш $1877 \mathrm{a}=$ Кулиш П. А. Казаки по отношению к государтсву и обществу. Русский Архив 1877/3: 352-368.

Кулиш $1877 \mathrm{~b}=$ Кулиш П. А. Казаки по отношению к государтсву и обществу. Русский Архив 1877/6: 113-135.

Кулиш 1885 = Кулиш П. А. Воспоминания о Николае Ивановиче Костомарове. Новь 1885/13: 63-75.

Кулиш 1888 = Кулиш П. А. Отпадение Малороссии от Польши (1340-1654). Т. 2. Москва, 1888.

Кулиш 1889 = Кулиш П. А. Отпадение Малороссии от Польши (1340-1654). Т. 3. Москва, 1889.

ЛАЗАРЕВА 2015 = ЛАЗАРЕВА В. Т. Соціотворчий потенціал філософських поглядів Панталеймона Куліша. Дис. канд. філос. наук. Київ, 2015. 
МАКСИМОВич 2004 = МАКСимович М. А. Письма о Богдане Хмельницком. Вибрані твори. Київ, 2004. 192-235.

Пинчук 1984 = Пинчук Ю. А. Исторические взгляды Н. И. Костомарова. Критический очерк. Киев, 1984.

Пинчук 2012 = Пинчук Ю. А. Вібрани студії з костомаровознавства. Київ, 2012.

СвІтЛЕнко 2016 = СвІтЛЕнко С. І. Історія України в історіософському осягненні молодого П. О. Кулиша. Вісник Дніипропетровського університету. Серія «Історія та археологія» 24 (2016): 22-32.

СондЕРС 2001 = СондЕРС Д. Микола Костомаров і творення української етнічної ідентичності. Київська старовина 2001/5: 21-32.

Товариство 1990 = Кирилло-Мефодївське товариство. Т. 1. Київ, 1990.

Ясь 2007 = Ясь О. Историчні погляди Панталеймона Кулиша в світли інтелектуальних метаморфоз 1870-1880-х років. Істориографичні дослідження в Украйни 17. Київ, 2007. 78-105. 